Darsyaf Hadi Wijaya. Kualitas Layanan Media Reservasi Kamar Hotel Terhadap Kepuasan Pelanggan.....133

\title{
UALITAS LAYANAN MEDIA RESERVASI KAMAR HOTEL TERHADAP KEPUASAN PELANGGAN DI PT. JAYA PRIMA UTAMA LESTARI TOUR AND TRAVEL BANDUNG
}

\author{
Darsyaf Hadi Wijaya \\ Politeknik Pariwisata Negeri Makassar, Sulawesi Selatan, Indonesia \\ Email: darsyaf_hadi@yahoo.com
}

\begin{abstract}
Abstrak: Kualitas Layanan Media Reservasi Kamar Hotel Terhadap Kepuasan Pelanggan Di PT. Jaya Prima Utama Lestari Tour And Travel Bandung. Travel agent merupakan perusahaan yang bergerak di bidang jasa, oleh sebab itu kualitas jasa yang baik merupakan salah satu strategi penting bagi suatu travel agent untuk memuaskan pelanggannya karena kepuasan pelanggan inilah yang mendorong intensitas pembelian produk yang ditawarkan. Dalam penelitian ini penulis ingin mengetahui bagaimana kualitas layanan media reservasi produk kamar hotel di PT. Jaya Prima Bandung, dari layanan media itulah penulis akan mengukur tingkat kepuasan pelanggan melalui persepsi dan ekspektasinya serta sejauh mana pengeruh kualitas layanan media reservasi hotel terhadap kepuasan pelanggan. Dalam melaksanakan penelitian ini, menggunakan metode deskriptif. Teknik pengumpulan data adalah dengan wawancara, penyebaran kuesioner, dan observasi. Unit analisis adalah analisis media reservasi hotel, analisis kualitas layanan, analisis persepsi dan ekspektasi.

Simpulan penelitian ini adalah bahwa penilaian persepsi pelanggan terhadap kualitas layanan media reservasi dalam kategori cukup. Namun masih ada aspek-aspek yang masih harus mendapat perhatian untuk ditingkatkan. Untuk ekspektasi pelanggan terhadap semua aspek dimensi kualitas layanan media reservasi hotel dianggap penting bagi konsumen yang melakukan layanan reservasi hotel melalui media. Hubungan antara kualitas layanan media reservasi hotel dengan kepuasan pelanggan yang melakukan reservasi hotel melalui media bisa dikategorikan hubungan yang kuat, hal ini didapat dari perhitungan korelasi antara variable kualitas layanan media reservasi dan kepuasan pelanggan. Hasil tersebut membuktikan dugaan penulis bahwa pelanggan akan baru merasa puas apabila kualitas layanan media reservasi hotel yang diberikannya memiliki suatu yang standar tertentu sesuai dengan apa yang diharapkan oleh pelanggan yang melakukan reservasi tersebut.
\end{abstract}

Kata Kunci : Media Reservasi; Kepuasan Pelanggan; Jaya Prima. 


\section{PENDAHULUAN}

Perkembangan pariwisata dewasa ini mengalami kemajuan yang cukup pesat, seiring dengan berkembangnya ilmu pengetahuan dan tekhnologi yang semakin meningkat, maka bentuk dari kegiatan berwisata itu sendiri berkembang menjadi suatu kegiatan yang bersifat umum dan luas. Kegiatan pariwisata bukan hanya tentang keindahan alam dan objek wisatanya saja namun transportasi dan akomodasi ikut pula berperan serta di dalamnya. Akomodasi atau perhotelan di Indonesia sejauh ini telah berkembang pesat, telah banyak hotelhotel dibangun sejalan dengan berkembangnya jumlah wisatawan baik domestik maupun internasional yang melakukan perjalanan dan menggunakan akomodasi baik secara langsung ataupun diatur oleh Biro Perjalanan Wisata atau Travel Agent.

Berdasarkan lingkup kegiatannya, Travel agent merupakan perusahaan yang bergerak di bidang jasa, oleh sebab itu kualitas jasa yang baik merupakan salah satu strategi penting bagi suatu travel agent untuk memuaskan pelanggannya karena kepuasan pelanggan inilah yang mendorong intensitas pembelian produk yang ditawarkan, oleh sebab itu telah menjadi hal yang umum apabila setiap biro perjalanan atau travel agent menekankan faktor kualitas pelayanan terhadap pelanggan dalam menjual produknya, selain kualitas pelayanan faktor-faktor yang dapat menunjang keberhasilan perusahaan biro dan agen perjalanan untuk tetap eksis dan berkembang antara lain : variasi dan mutu produk, keahlian staf penjualan, promosi dan penggunaan media reservasi yang efektif.

Dengan melihat tekhnologi yang kian berkembang dan sistem pemesanan kamar hotel yang dapat diakses melalui jaringan internet, maka peran serta Biro Perjalanan Wisata yaitu PT. Jaya Prima Utama Lestari Tour and Travel Bandung sebagai perantara dalam penjualan reservasi kamar hotel yang kebanyakan menggunakan media telepon dan fax akan sedikit berpengaruh dalam keefektifannya walaupun sejauh ini penerapan online reservation yang berupa e-mail di PT. Jaya Prima Utama Lestari Tour and Travel Bandung telah ada tetapi masih belum terlalu memberi kontribusi yang efektif dalam proses reservasi kamar hotel. Begitu pula dengan masalah pelayanan yang dilakukan oleh PT. Jaya Prima mereka telah berusaha melakukan peningkatan mutu pelayanan bagi 
konsumen. Salah satu contoh mutu pelayanan yang dilakukan, misalnya para petugas reservasi selalu berada di tempat mereka masing-masing agar para konsumen bisa secara langsung memperoleh apa yang dibutuhkannya, selain itu pemberian informasi yang akurat dan tepat, juga keramah-tamahan para petugas reservasi juga merupakan mutu pelayanan yang baik. Sedangkan salah satu contoh fasilitas yang ada di PT. Jaya Prima adalah berbagai media yang digunakan dalam reservasi kamar hotel baik untuk pemesanan kamar ke hotel ataupun menerima reservasi dari konsumen. PT. Jaya Prima berupaya membangun citra positif dengan mutu pelayanan yang baik dan menyediakan fasilitas bagi konsumennya. Hal inilah yang akan penulis ukur dan teliti sejauh mana mutu pelayanan yang diberikan PT. Jaya Prima dalam reservasi kamar Hotel melalui berbagai media reservasi yang digunakan. Sesuai dengan latar belakang masalah yang telah diuraikan maka indentifikasi masalahnya adalah : 1). Bagaimana persepsi dan ekspektasi konsumen terhadap kualitas layanan media reservasi kamar hotel di PT Jaya Prima Utama Lestari Tour and Travel Bandung? 2). Bagaimana tingkat kepuasan pelanggan dalam melakukan reservasi kamar hotel di PT Jaya Prima Utama Lestari Tour and Travel Bandung? 3). Sejauh mana pengaruh kualitas layanan media reservasi kamar hotel terhadap kepuasan pelanggan di PT Jaya Prima Utama Lestari Tour and Travel Bandung ? Parasuraman et al (1990:1-2) berusaha mengetahui definisi dari mutu pelayanan melalui studi wawancara terhadap beberapa kelompok (Focused-groups) sehinga dapat diketahui pandangan konsumen tentang mutu pelayanan.

Kelompok-kelompok tersebut menyatakan bahwa kunci dari mutu pelayanan yang baik adalah menyesuaikan atau melebihi harapan konsumen dari jasa yang diberikan oleh perusahaan. Sehubungan dengan hal tersebut Parasuraman et al (1990:1-2) mengemukanan definisi mutu pelayanan sebagai berikut :“ service quality, as perceived by customers, can be defined as the extent of discrepancy between customers' expectations or desire and their perceptions" Definisi tersebut berarti bahwa dari penerimaan mutu pelayanan seperti yang dirasakan oleh konsumen, kualitas jasa merupakan tingkat perbedaan antara harapan atau keinginan konsumen dengan persepsinya terhadap jasa yang diterima. 
Selanjutnya Parasuraman et al., (1990 : 1-2) menjelaskan mengenai faktor-faktor yang dapat mempengaruhi harapan konsumen yaitu: komunikasi dari mulut ke mulut, kebutuhan individu, pengalaman masa lalu, dan komunikasi eksternal. Selain itu, mereka menyebutkan pula 10 dimensi umum yang mewakili kriteria penilaian yang digunakan konsumen untuk menilai mutu pelayan yaitu : tangibles (nyata), reliability (keterandalan), responsiveness (tanggung jawab), competence (kecakapan), courtesy (rasa hormat), credibility (kepercayaan), security (keamanan), access (kesempatan), communication (komunikasi), dan understanding the customer (memahami pelanggannya). Berdasarkan definisi mutu pelayanan dan 10 dimensi penilaian di atas, maka Parasuraman et al (1990:23) mengembangkan alat untuk mengukur mutu pelayanan yang disebut SERVQUAL. SERVQUAL ini berisi dua bagian, yaitu : 1). Bagian harapan yang berisi pertanyaan untuk mengetahui harapan umum dari konsumen yang berhubungan dengan pelayanan (jasa). 2). Bagian persepsi yang berisi pernyataan yang sesuai dengan bagian harapan, untuk mengukur penilaian konsumen terhadap mutu pelayanan perusahaan yang diteliti. yang kompleks (Fandy Tjiptono, 2006:349).
Pada SERVQUAL, 7 dimensi umum

kriteria penilaian konsumen digolongkan dalam dua dimensi yang lebih luas yaitu assurance dan empathy, sehingga dimensi-dimensi dari SERVQUAL menurut Parasuraman et al (1990 :26) adalah sebagai berikut :1). Tangibles : tampilan fisik dari fasilitas, peralatan, personalia, dan materi komunikasinya. 2). Reliability : kemampuan untuk mewujudkan jasa yang dijanjikan dapat diandalkan dan dilaksanakan secara akurat. 3). Responsiveness : kemauan untuk membantu dan menyediakan jasa yang tepat kepada konsumen. 4). Assurance : pengetahuan dan keramahan pegawai serta kemampuan untuk merebut kepercayaan dan keyakinan konsumen. 5). Empathy: kepedulian dan perhatian per individu yang di terapkan perusahaan dalam mengahadapi konsumennya. kepuasan atau satisfaction berasal dari bahasa latin "satis" (artinya cukup baik, memadai) dan "facio" (melakukan atau membuat). Secara sederhana kepuasan dapat diartikan sebagai "upayapemenuhansesuatuatau membuat sesuatu memadai". Namun, ditinjau dari perspektif perilaku konsumen, istilah "kepuasan konsumen" lantas menjadi sesuatu 
Menurut Engle dalam Rambat Lupiyodo dalam buku yang sama (2006:146) menjelaskan bahwa kepuasan konsumen merupakan evaluasi purna beli di mana alternatif yang dipilih sekurangkurangnya memberikan hasil yang sama atau melampaui harapan konsumen, sedangkan ketidakpuasan akan timbul apabila hasil yang didapat tidak memenuhi harapan konsumen.

Kepuasan konsumen juga dipandang sebagai salah satu indikator terbaik untuk laba masa depan (Kotler, 2000). Kenyataan bahwa menarik konsumen baru jauh lebih mahal dari pada mempertahankan konsumen saat ini juga menjadi salah satu pemicu meningkatnya perhatian pada kepuasan konsumen. Sedangkan menurut Mown (1995:512) oleh Fandy Tjiptono dalam buku Pemasaran Jasa (2006:350), kepuasan konsumen merupakan sebagai sikap keseluruhan terhadap sesuatu barang atau jasa setelah perolehan dan pemakaian. Dengan kata lain, kepuasan konsumen merupakan penilaian evaluatif purna beli terhadap suatu produk atau jasa.

Pada dasarnya kepuasan dan ketidakpuasan konsumen atas produk akan berpengaruh pada pola perilakunya, selanjutnya apabila konsumen merasa puas maka dia Menurutnya, faktor utama penentu kepuasan akan menyebabkan besarnya kemungkinan untuk mebeli prodak yang sama, dan biasanya konsumen yang puas cenderung akan memberikan referensi yang baik terhadap produk yang dibelinya kepada orang lain. Sebaliknya, konsumen yang tidak puas dapat melakukan tidakan gugatan terhadap perusahaan tersebut. Hal ini harus dapat diantisipasi oleh perusahaan karena seorang konsumen yang tidak puas akan merusak citra perusahaan (Kotler 1997, dalam buku Rambat Lupiyoadi). Banyak manfaat yang diterima perusahaan dengan tercapainya tingkat kepuasan konsumen yang tinggi, antara lain; meningkatkan loyalitas konsumen dan mecegah perputaran konsumen, mengurangi sensitifitas konsumen terhadap harga, mengurangi biaya operasional yang diakibatkan meningkatnya jumlah konsumen, dan meningkatnya reputasi bisnis (Fornel, 1992 dalam buku Rambat Lupiyoadi).

Selain dari beberapa pengertian tentang kepuasan konsumen tersebut, Kotler dalam Tjiptono (2000:146) mengatakan pula bahwa kepuasan konsumen adalah tingkat perasaan seseorang setelah membandingkan hasil yang ia rasakan dibandingkan dengan harapannya. 
konsumen adalah persepsi konsumen terhadap kualitas jasa yang diberikan, yaitu perbedaan antara pelayanan yang disediakan oleh perusahaan jasa dan pelayanan yang diharapkan diterima oleh konsumen (ekspektasi). Teori tersebut dikuatkan oleh Hsu, Cathy H. C. and Powers, Tom (Marketing Hospitality, 2009) yang menyatakan: "Service quality is the difference between the quality of service provided by a specific hospitality and travel organisation and the quality of service customers expect to receive from similar hospitality and travel organitation

Menurut John R. Rossiter, Larry Percy (1998, p. 419) “Media are the means of delivering the creative message to thereby achieve the communication objectives of the campaign". Dari definisikan diatas dapat diartikan bahwa media merupakan penyaluran pesan yang kreatif bagi para penerimanya untuk mencapai tujuan kampanye komunikasi. Menurut K. Suhandang dalam bukunya Manajemen kiat dan strategi, media dapat dogolongkan bedasarkan sifatnya, yaitu terbagi atas tiga golongan: 1). Auditif, adalah media yang sifatnya bisa secara lisan atau biasa disebut the spoken word. 2). Visual, adalah media yang sifatnya secara tertulis atau nampak dan biasa disebut the printed word. 3).
Audiovisual, adalah media perpaduan antara gambar atau tulisan dengan suara

Dikaitkan dengan penggolongan media di atas, dalam pemesanan kamar hotel, khususnya di setiap Biro perjalanan sebagai perantara, tedapat tiga media yang sering digunakan. yaitu: 1). Telepon. Telepon adalah suatu alat komunikasi yang dapat mengirimkan percakapan melalui signal elektrik. Telepon berasal dari kata tele dan phone yang merupakan bahasa Yunani. Tele berarti jauh, dan phone berarti suara atau bunyi. Telepon ditemukan oleh Alexander Graham Bell pada tahun 1876 ("Telephone"). Menurut P.A Garner dalam bukunya Using the telephone effectively (1993) telepon mempunyai beberapa kelebihan dalam penggunaannya, yaitu telepon digunakan untuk melengkapi komunikasi di dalam lingkungan komunikasi yang tidak lengkap, dan berfungsi untuk menangkap petunjuk yang benar dibatasi oleh tidak adanya informasi visual. Menggunakan telepon dengan efektif berarti menggunakan cara mendengarkan aktif untuk mengendalikan dan menuntun percakapan. Tetapi telepon juga mempunyai kekurangan yaitu konteks dan kesan visual adalah satusatunya bagian dari apa yang tidak dimiliki 
sewaktu berbicara lewat telepon (1993, p. Namun fax juga mempunyai kekurangan, yaitu 2), kecuali pada ,video calle yang saat ini terkadang kualitas dari dokumen yang dikirim mulai dikembangkan oleh perusahaan telepon sangat memprihatinkan, dan tidak semua orang selurer. Dalam dunia pariwisata terutama dalam mempunyai mesin fax dirumahnya ( 1993, p. reservasi kamar hotel, khususnya melalui Biro 13 ). Selain sebagai sarana berkirim dokumenPerjalanan, telepon juga memiliki peranan dokumen penting yang berhubungan dengan penting sebagai alat komunikasi dan juga industri, fax juga digunakan sebagai sebagai digunakan untuk menerima reservasi kamar salah satu media untuk menerima reservasi hotel. 2). Fax. Facsimile atau telefacsimile (fax) kamar hotel. 3). Internet. Internet meupakan adalah suatu teknologi telekomunikasi yang kepanjangang dari Interconnection Networking. digunakan untuk mentransfer salinan dokumen Menurut Grant ( 1996, p. 132) internet dengan menggunakan alat operasi jaringan merupakan cara menghubungkan jaringantelepon. Fax detemukan oleh Rudolf Hell pada jaringan lokal yang kecil(LAN) kedalam sebuah tahun 1929 dan menjadi sangat populer ditahun database global yang proporsinya menakjubkan 1980-an. Kegunaannya adalah untuk mentrasfer dengan akses bebas. Beberapa layanan penting satu atau banyak dokumen baik halaman yang disediakan oleh internet meliputi surat yang dicetak ataupun tulisan tangan dalam elektronik, transfer dokumen, akses dalam warna hitam putih ("Facsimile"). Fax banyak mengendalikan sistem komputer melalui telnet digunakan dalam berbagai bidang industri, dan Gopher, newsgroups dan mailing list, serta termasuk industri Perjalanan Wisata. Adapun World Wide Web. Sedangkan menurut Engst, beberapa keuntungan jika menggunakan Low, dan Simon(1995, p. 17), internetterdiri dari media fax menurut garner adalah fax menjadi sejumlah besar pemakai, komputer-komputer lebih efektif dari telepon, voice mail atau yang saling berhubungan, program-program e-mail, saat pesan itu bersifat panjang dan software dan berbagai informasi yang terbesar membingungkan, saat dokumen perlu untuk diseluruh dunia yang menjalin hubungan secara diteliti dan didiskusikan dengan segara, atau berkesinambungan. Menurut La Quey (1997, saat partisipan menginginkan sebuah data. p. 1) internet merupakan jaringan yang luas 
yang terdiri dari ribuan jaringan komputer yang menjangkau jutaan orang di seluruh dunia. Sekarang ini internet telah berkembang menjadi suatu alat komunikasi yang sangat cepat dan efektif serta menjadi alat penyebaran informasi yang tidak terbatas dengan beragam pengguna dan kepentingannya. Di antaranya layanan secara online yang dapat didefinisikan sebagai jaringan komputer yang tersusun atas informasi perpustakaan, belanja, dan layanan komersial, serta e-mail yang dapat digunakan oleh konsumen.

\section{METODE PENELITIAN}

Jenis penelitian yang digunakan dalam penelitian ini yaitu Analisis kuantitatif dengan teknik analisis Statistik Deskriptif. Analisis statistik deskriptif adalah statistik yang digunakan untuk menganalisis data dengan cara mendeskripsikan atau menggambarkan

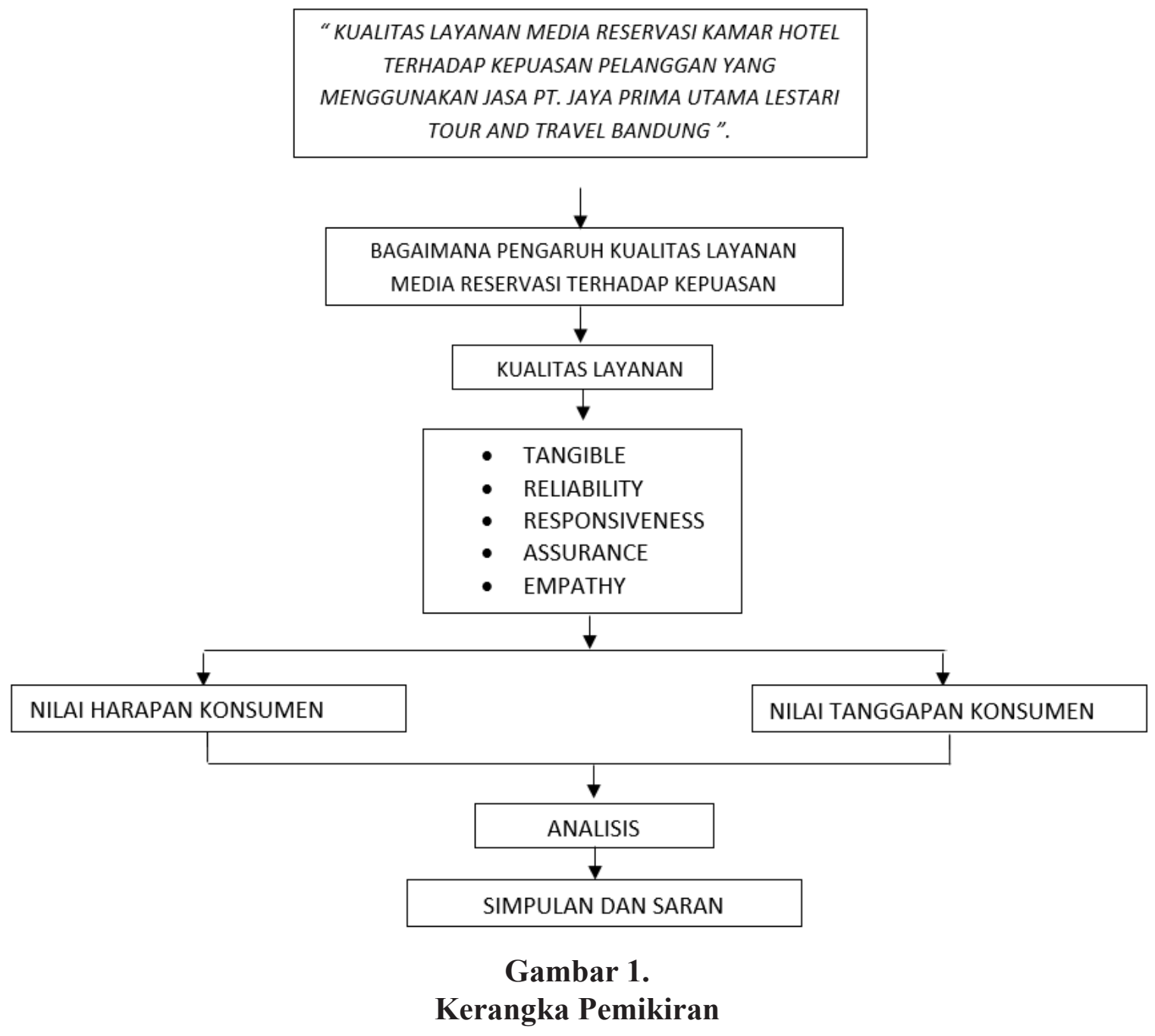


data yang telah terkumpul sebagaimana adanya tanpa bermaksud membuat kesimpulan yang berlaku untuk umum atau generalisasi. Selain itu penelitian ini juga menggunakan teknik pengolahan data Importance Performance Analysis (IPA) yang dimana tingkat kepentingan pelanggan (customer expectation) diukur dalam kaitannya dengan kinerja perusahaan, selanjutnya memetakan hasil perhitungan yang telah didapat ke dalam Diagram Kartesius.

Populasi yang digunakan dalam penelitian ini adalah seluruh konsumen yang pernah menggunakan jasa reservasi kamar hotel di PT. Jaya Prima Utama Lestari Tour and Travel Bandung selama 3 bulan terakhir, yang jumlahnya diketahui sebanyak 30 pelanggan. Sampel merupakan bagian yang dimiliki oleh populasi tersebut. Teknik yang dipakai untuk mengambil jumlah sampel yaitu teknik sensus, dengan mengambil seluruh jumlah populasi dari konsumen yang pernah melakukan jasa reservasi kamar hotel di PT. Jaya Prima Utama Lestari Tour and Travel Bandung selama 3 bulan terakhir Maka sampel yang akan di ambil hanya berjumlah 30 orang.

Berdasarkan pendapat Arikunto (2006: 100), apabila subjek dari sampel kurang dari
100 maka lebih baik diambil seluruhnya. Dengan demikian, maka sampel dari penelitian ini adalah 30 responden yang pernah melakukan jasa reservasi kamar hotel di PT. Jaya Prima Utama Lestari Tour and Travel Bandung selama 3 bulan terakhir.

Teknik dan alat kumpul Data yang digunakan antara lain: Observasi lapangan dan Penyebaran kuesioner, selain itu Teknik Analisis Data yang digunakan adalah metode analisis statistical Package For social Science (SPSS). Program yang penulis gunakan adalah SPSS versi 16.00, dimana dapat mengelola data untuk menghasilkan data yang mendukung dalam penelitian ini, yang meliputi : frekuensi, grafik, standar deviasi, persentase, dan diagram pareto. Untuk melakukan analisis korelasi anatara variabel penulis akan mengunakan metode korelasi spearman Rank dalam bentuk SPSS untuk mengetahui tingkat hubungan variabel X (kualitas layanan media) dengan variabel Y (kepuasan pelanggan). Dalam rangka mengetahui pelaksanaan program mana yang perlu diperbaiki, ditingkatkan atau diganti, peneliti menggunakan analisa Diagram Kartesius. 


\section{HASIL DAN PEMBAHASAN}

\section{Analisis Kualitas Layanan Media} Reservasi Kamar Hotel di PT. Jaya Prima Utama Lestari Bandung. Berdasarkan hasil penyebaran kuesioner yang telah penulis lakukan, pada bagian ini penulis akan menganalisis mengenai kualitas layanan media reservasi kamar hotel PT. Jaya Prima Bandung yang mencakup lima dimensi kualitas layanan yaitu tangibles, realibility, responsiveness, assurance dan empathy berdasarkan persepsi dan ekspektasi pelanggan. Analisis tersebut disusun mengacu pada matriks operasional variable yang datanya merupakan hasil survey terhadap 30 responden yaitu para konsumen dari PT Jaya Prima Utama Lestari Bandung yang telah menggunakan jasa reservasi kamar hotel. Nilai rata-rata kualitas layanan berdasarkan persepsi dari para responden:ditunjukan pada Tabel 1.
Pada Tabel 1 dapat dilihat bahwa nilai rata-rata persepsi pelanggan terhadap kualitas layanan media reservasi di PT. Jaya Prima Bandung adalah sebesar 3,20. Apabila nilai tersebut dikonversikan kepada persentase (\%), maka akan diperoleh angka: 3,20/5 x 100\% $=64 \%$ yang berarti “cukup". Aspek yang nilainya tertinggi dari persepsi konsumen terhadap kualitas layanan berada pada aspek "Respond dan tanggapan petugas dalam membalas reservasiee yaitu sebesar 4,47 (Tabel 59) yang berarti aspek tersebut dinilai sangat baik oleh para konsumen. Sedangkan untuk aspek yang nilainya terendah berada pada aspek "Kemudahan menghubungi PT. Jaya Prima melalui telepon" dengan angka hanya sebesar 2,77 atau 55,40\%. Nilai rata-rata dari kelima dimensi kualitas layanan berdasarkan persepsi konsumen ditunjukan pada Tabel 2.

Tabel 1.

Nilai Rata-Rata Analisis Persepsi Kualitas Layanan

\begin{tabular}{lccccc}
\hline & N & Minimum & Maximum & Mean & Std. Deviation \\
\hline Persepsi Kualitas & 22 & 2.77 & 4.47 & 3.2036 & .31473 \\
Layanan & & & & & \\
Valid N (listwise) & 22 & & & \\
\hline
\end{tabular}

Sumber: Output SPSS, 2020 
Tabel. 2

Deskripsi Analisis Ekspetasi Kualitas Layanan

\begin{tabular}{lccccc}
\hline & N & Minimum & Maximum & Mean & Std. Deviation \\
\hline Ekspektasi Kualitas & 22 & 3.17 & 3.83 & 3.3950 & .14940 \\
Jasa & & & & & \\
Valid N (listwise) & 22 & & & & \\
\hline
\end{tabular}

Sumber: Output SPSS, 2020

Pada Tabel 2 dapat dilihat bahwa media reservasi kamar hotel digunakan rumus nilai rata-rata ekspektasi pelanggan terhadap SERVQUAL (P besar atau sama E) sebagai kualitas layanan media reservasi di PT. Jaya berikut:

Prima Bandung adalah sebesar 3,39. Untuk memperoleh angka persentasenya, nilai tersebut dikalkulasikan dengan cara sebagai berikut: $3,39 / 5 \times 100 \%=68 \%$ yang berarti „cukup pentingee. Nilai tertinggi dari expektasi pelanggan berada pada aspek proses tanya-jawab dengan petugas reservasi sebesar 3,83 dan nilai ini dikatakan ,pentingee. Sedangkan untuk aspek yang nilainya terendah berada pada penggunaan kata oleh petugas reservasi dalam mengirim data dan aspek kemudahan menghubungi PT. Jaya Prima melalui telepon yaitu sebesar 3,17 yang berarti nilai ini dikatakan "cukup pentingee

Berdasarkan penghitungan statistik, diperoleh data persepsi pelanggan sebesar 3,20 sedangkan nilai ekspektasi (harapan) sebesar 3,39. Untuk menghitung tingkat kepuasan pelanggan terhadap kualitas layanan

$$
\begin{aligned}
\mathrm{NX} & =\mathrm{NP}-\mathrm{NE} \\
\mathrm{NX} & =\mathrm{NP}-\mathrm{NE} \\
\mathrm{NX} & =3,20-3,39 \\
& =-0,19
\end{aligned}
$$

Berdasarkan penghitungan SERVQUAL antara kepuasan pelanggan terhadap kualitas layanan terdapat selisih antara nilai persepsi konsumen dengan nilai ekspektasi (harapan) pelanggan sebesar - 0,19. Nilai tersebut menunjukkan bahwa tingkat kepuasan pelanggan dalam menggunakan layanan media reservasi hotel di PT. Jaya Prima Bandung belum dapat dipenuhi sepenuhnya. Hal ini dikarenakan adanya beberapa aspek dari dimensi kualitas layanan media reservasi hotel yang berada di bawah nilai ekspektasi konsumen Kondisi ini akan berdampak terhadap ketidakpuasan konsumen dalam melakukan reservasi kamar hotel melalui PT. Jaya Prima. 
Berdasarkan teori yang telah dibahas pada Bab terdahulu, faktor utama penentu kepuasan pelanggan adalah persepsi pelanggan terhadap kualitas jasa yang diberikan oleh perusahaan. Kualitas jasa merupakan perbedaan dari pelayanan yang disediakan oleh perusahaan jasa (persepsi) dan pelayanan yang diharapkan oleh pelanggan (ekspektasi) untuk didapat dari perusahaan tersebut. Oleh sebab itu, kepuasan pelanggan ditentukan oleh persepsi pelanggan terhadap kualitas layanan dan pelanggan akan merasa puas apabila harapannya terpenuhi atau akan sangat puas bila harapannya terlampaui. terpuaskan.

Sehubungan dengan hal tersebut, pelanggan yang

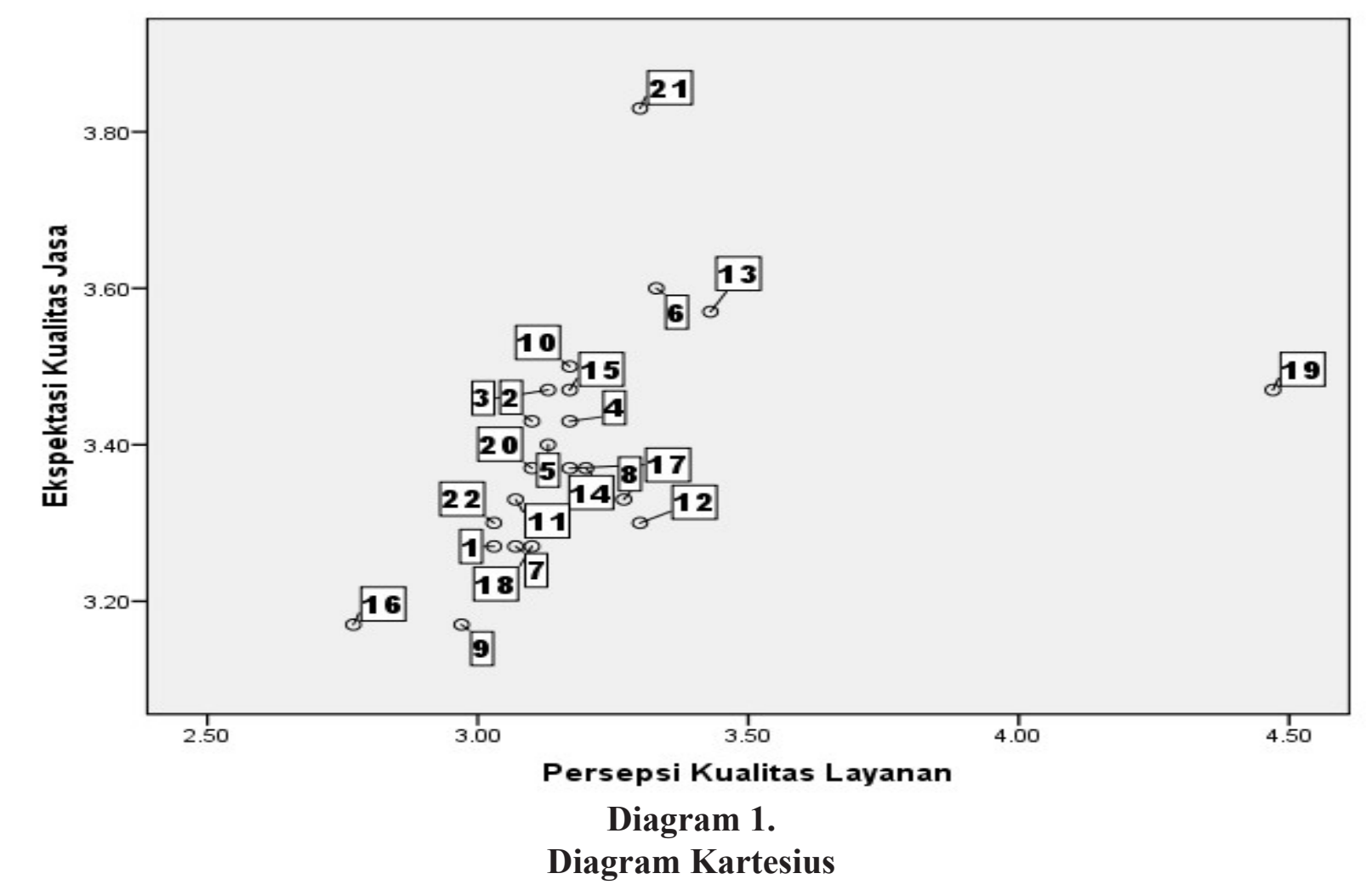

Sumber: Output SPSS, 2020

merasa puas akan menunjukkan kecenderungan untuk membeli jasa atau produk yang sama dan biasanya mereka akan memberikan referensi yang baik kepada orang lain.

Pada aspek persepsi konsumen terhadap kualitas layanan media reservasi hotel di PT. Jaya Prima Bandung, nilai tertingginya adalah sebesar 4,47 dan nilai terendanya sebesar 2,77. Hal ini berarti persepsi pelanggan dari kelima dimensi kualitas layanan media reservasi hotel berada di bawah ekspektasi mereka atau dengan kata lain: kebutuhan konsumen belum

\section{terpuaskan.}


Aspek ekspektasi (harapan) pelanggan menunjukkan nilai sebesar 3,83 yang berarti harapan pelanggan sangat besar terhadap pelayanan yang diberikan dalam melakukan reservasi hotel melalui media di PT. Jaya Prima Bandung. Oleh sebab itu, terdapat kesenjangan antara persepsi dan ekspektasi pelanggan pada saat melakukan reservasi kamar hotel melalui media reservasi di PT. Jaya Prima Bandung.

Untuk melihat hal-hal apa saja dari dimensi kualitas layanan yang belum dan telah mencapai kepuasan pelanggan ditunjukan pada Diargram 1. Pada Diagram 1 dapat dilihat faktorfaktor dimensi kualitas layanan yang masuk kategori puas dan yang belum memuaskan bahkan ada juga yang over acting dan biasabiasa saja. Untuk lebih jelasnya, faktor-faktor di kategorikan dalam empat hal yang dapat dilihat pada Tabel 3.

Dari keempat kategori pada Tabel 3 ada beberapa tindakan yang hendaknya dilakukan untuk bisa memperbaiki kondisi pelayanan tersebut. Apabila dimensi berada pada kategori sangat memuaskan maka hal itu harus tetap dipertahankan untuk dapat menjaga kualitas layanan yang diberikan kepada pelanggan. Apabila dimensi berada dalam kategori tidak puas maka pelayanan harus ditingkatkan dan diperbaiki lagi kualitasnya agar dapat mencapai tingkat kepuasan pelanggan. Untuk dimensi yang berada pada kategori over acting maka kinerja harus dikurangi guna mengurangi cost operasional, tetapi tetap harus diperhatikan dan dikontrol keseimbangan kinerjanya sebab pelayanan juga tidak boleh terlalu kurang optimal. Apabila dimensi berada pada kategori tidak penting maka kinerja ini dapat dihilangkan, tetapi apabila tidak terlalu banyak memakan biaya operasional sebaiknya dipertahankan guna menambah layanan bagi para pelanggan.

Berdasarkan analisis tingkat kepuasan konsumen dalam melakukan reservasi hotel melalui media di PT. Jaya Prima Bandung yang dilihat dari persepsi dan ekspektasi pelanggan serta dari tingkat kepentingannya yang telah diukur melalui diagram Kartesius, maka dapat dikatakan bahwa tingkat kepuasan konsumen belum semuanya terpenuhi dikarenakan masih adanya kesenjangan antara beberapa faktor persepsi dengan ekspektasi pelanggan pada saat melakukan reservasi hotel melalui media reservasi di PT. Jaya Prima Bandung.

Analisis mengenai sejauh mana hubungan antara kualitas layanan media 
Tabel 3.

\section{Faktor-Faktor Dimensi Kualitas Layanan}

\begin{tabular}{|c|c|}
\hline Kategori & Keterangan \\
\hline \multirow{9}{*}{ Memuaskan } & $\begin{array}{l}\text { Dimensi no. } 4 \text { yaitu dengan "Kelengkapan informasi mengenai hotel-hotel di tempat tujuan pada } \\
\text { situs PT. Jaya Prima". }\end{array}$ \\
\hline & $\begin{array}{l}\text { Dimensi no. } 6 \text { yaitu "Kelengkapan informasi dari data reservasi yang di kirim oleh PT. Jaya Prima } \\
\text { melalui media fax". }\end{array}$ \\
\hline & $\begin{array}{l}\text { Dimensi no. } 8 \text { yaitu "Frekuensi waktu oleh petugas reservasi dalam membalas reservasi yang } \\
\text { diinginkan tamu". }\end{array}$ \\
\hline & Dimensi no. 10 yaitu "Penanganan reservasi melalui telepon oleh petugas PT. Jaya Prima". \\
\hline & Dimensi no. 13 yaitu "Kejelasan informasi yang diberikan melalui media telephone". \\
\hline & $\begin{array}{l}\text { Dimensi no. } 15 \text { yaitu "Kemudahan dalam memperoleh informasi mengenai hotel-hotel di tempat } \\
\text { tujuan pada situs PT. Jaya Prima". }\end{array}$ \\
\hline & $\begin{array}{l}\text { Dimensi no } 17 \text { yaitu dengan pertanyaan, "Bagaimana kemudahan dalam menghubungi PT. Jaya } \\
\text { Prima melalui media telepon?" }\end{array}$ \\
\hline & $\begin{array}{l}\text { Dimensi no } 19 \text { yaitu "Respon dan tanggapan petugas reservasi dalam membalas reservasi yang } \\
\text { diinginkan tamu" }\end{array}$ \\
\hline & $\begin{array}{l}\text { Dimensi no } 21 \text { yaitu "Kenyamanan dalam melakukan reservasi melalui media telepon ke PT. Jaya } \\
\text { Prima". }\end{array}$ \\
\hline \multirow{3}{*}{ Tidak Puas } & $\begin{array}{l}\text { Dimensi no. } 2 \text { yaitu "Tampilan dan desain situs PT Jaya Prima sebagai media reservasi hotel." } \\
\text { Dimensi no. } 3 \text { yaitu "Bentuk informasi yang di dapat tamu melalui situs PT Jaya Prima". }\end{array}$ \\
\hline & $\begin{array}{l}\text { Dimensi no. } 5 \text { yaitu, "Kelengkapan informasi mengenai hotel-hotel di tempat tujuan yang } \\
\text { diberikan oleh petugas melalui media telepon". }\end{array}$ \\
\hline & $\begin{array}{l}\text { Dimensi no. } 20 \text { yaitu "Proses tanya-jawab dengan petugas reservasi dalam pemesanan kamar } \\
\text { hotel melalui media telepon". }\end{array}$ \\
\hline \multirow[b]{2}{*}{ Over Acting } & Dimensi no. 12 "Penanganan reservasi melalui fax oleh petugas PT. Jaya Prima". \\
\hline & $\begin{array}{l}\text { Dimensi no. } 14 \text { yaitu "Kejelasan informasi dari data reservasi yang di kirim oleh PT. Jaya Prima } \\
\text { melalui media fax" }\end{array}$ \\
\hline \multirow{6}{*}{$\begin{array}{c}\text { Tidak } \\
\text { Penting }\end{array}$} & $\begin{array}{l}\text { Dimensi no. } 1 \text { yaitu "Tampilan dan disain hasil dari data yang dikirim oleh PT. Jaya Prima melalui } \\
\text { media fax" }\end{array}$ \\
\hline & $\begin{array}{l}\text { Dimensi no. } 7 \text { yaitu "Kelancaran komunikasi pemesanan kamar hotel melalui situs PT. Jaya } \\
\text { Prima". } \\
\text { Dimensi no. } 9 \text { yaitu "Penggunaan kata dan kalimat yang digunakan oleh petugas reservasi dalam } \\
\text { mengirim data reservasi". }\end{array}$ \\
\hline & $\begin{array}{l}\text { Dimensi no. } 11 \text { yaitu "Cara pelayanan reservasi hotel yang dilakukan petugas reservasi melalui } \\
\text { media telepon". }\end{array}$ \\
\hline & $\begin{array}{l}\text { Dimensi no. } 16 \text { yaitu "Kemudahan dalam melalukan reservasi hotel melalui fax ke PT. Jaya } \\
\text { Prima". }\end{array}$ \\
\hline & Dimensi no. 18 yaitu "Kejernihan sinyal dan frekuensi pengangkatan telepon di PT. Jaya Prima". \\
\hline & $\begin{array}{l}\text { Dimensi no. } 22 \text { yaitu "Pengulangan kembali reservasi yang diinginkan tamu oleh petugas } \\
\text { reservasi sebelum menutup telepon". }\end{array}$ \\
\hline
\end{tabular}

Sumber: Data diolah, 2020

reservasi terhadap kepuasan konsumen saat Untuk mengetahui sejauh mana hubungan melakukan reservasi hotel adalah dengan tersebut, penulis menggunakan teknik analisis membahas atau menguraikan sejauh mana korelasi Spearman Rank dengan menggunakan variabel kualitas layanan media reservasi alat bantu SPSS 16. Data yang digunakan berpengaruh terhadap kepuasan konsumen. dalam korelasi tersebut adalah data hasil olahan 
kuesioner tentang persepsi pelanggan terhadap kualitas layanan media reservasi (X) dan data hasil olahan kuesioner tentang kepuasan konsumen dalam menggunakan layanan media reservasi (Y), yang ditunjukkan dalam Tabel 4.

Pada Tabel 4 dapat dilihat bahwa korelasi antara kualitas layanan media reservasi (X) dengan kepuasan pelanggan (Y) adalah sebesar 0,789. Jadi hubungan antara kualitas layanan media reservasi hotel dengan kepuasan pelanggan adalah hubungan yang kuat. Besarnya pengaruh hubungan yang kuat yaitu pengaruh variabel persepsi kualitas layanan media reservasi hotel terhadap kepuasan pelanggan relatif besar, yaitu $62,25 \%$ dan di bulatkan menjadi $62 \%$.
Faktor ini meliputi sesuatu yang berwujud seperi tampilan dan disain hasil dari data yang dikirim, kelengkapan informasi dari data reservasi yang di kirim melalui media, cara pelayanan reservasi hotel yang dilakukan petugas reservasi melalui media, kejelasan informasi yang diberikan melalui media, respon dan tanggapan petugas reservasi dalam membalas reservasi, dan lain sebagainya. Sedangkan sisanya yaitu $38 \%$ merupakan faktor-faktor lain yang mempengaruhi tingkat kepuasan konsumen yang melakukan reservasi kamar hotel melalui media di PT. Jaya Prima Bandung.

Faktor-faktor tersebut antara lain adalah pengalaman konsumen, rekomendasi dari pihak

Tabel 4.

Korelasi Variabel Kualitas Layanan Media Reservasi Terhadap Kepuasan Pelanggan

\begin{tabular}{|c|c|c|c|c|}
\hline & & & $\begin{array}{l}\text { Persepsi } \\
\text { Kualitas } \\
\text { Layanann }\end{array}$ & $\begin{array}{l}\text { Kepuasan } \\
\text { Pelanggan }\end{array}$ \\
\hline \multirow{6}{*}{$\begin{array}{l}\text { Spearman's } \\
\text { rho }\end{array}$} & \multirow[t]{3}{*}{$\begin{array}{l}\text { Persepsi Kualitas } \\
\text { Layanan }\end{array}$} & $\begin{array}{l}\text { Correlation } \\
\text { Coefficient }\end{array}$ & 1.000 & $.789^{* * *}$ \\
\hline & & Sig. (2-tailed) & . & .000 \\
\hline & & $\mathrm{N}$ & 30 & 30 \\
\hline & \multirow[t]{3}{*}{ Kepuasan Pelanggan } & $\begin{array}{l}\text { Correlation } \\
\text { Coefficient }\end{array}$ & $.789^{* * *}$ & 1.000 \\
\hline & & Sig. (2-tailed) & .000 & $\cdot$ \\
\hline & & $\mathrm{N}$ & 30 & 30 \\
\hline
\end{tabular}

Sumber: Output SPSS, 2020 
lain, komunikasi pemasaran, pengetahuan pelanggan tentang merek-merek pesaing lain yang dapat mempengaruhi ekspektasi seseorang sehingga ketika apa yang diterima oleh pelanggan (persepsi) berbeda dengan apa yang diharapkannya (ekspektasi) mengakibatkan adanya gap antara persepsi dengan ekspektasi dan jika perbedaannya ini terlalu jauh dapat menyebabkan pelanggan menjadi kecewa atau tidak puas dengan pelayanan yang diberikan leh PT. Jaya Prima Bandung.

Meskipun faktor-faktor lain akan memberikan pengaruh terhadap tingkat kepuasan konsumen, namun faktor utama kualitas layanan memegang peranan yang sangat besar terhadap kepuasan pelanggan dibandingkan dengan factor-faktor lainnya tersebut. Dengan kata lain, pelanggan baru akan merasa puas apabila kualitas layanan media reservasi kamar hotel yang dilakukan memilki suatu standar tertentu serta sesuai dengan apa yang diharapkan oleh mereka.

\section{SIMPULAN DAN SARAN}

Berdasarkan penelitian yang dilakukan oleh penulis serta didukung oleh data yang diperoleh dari hasil penelitian tersebut, maka penulis mengambil kesimpulan sebagai jawaban dari identifikasi masalah tentang kepuasan pelanggan di PT. Jaya Prima Bandung, sebagai berikut:1). Persepsi pelanggan terhadap kualitas layanan media reservasi hotel di PT. Jaya Prima Bandung.Berdasarkan analisis pada Bab IV dapat disimpulkan bahwa nilai rata-rata persepsi pelanggan terendah pada kualitas layanan media reservasi hotel terletak pada aspek 'Kemudahan menghubungi PT. Jaya Prima melalui media telepon' dengan nilai rata-rata sebesar 2,77. Sedangkan nilai rata-rata tertinggi berada pada aspek 'Respon dan tanggapan petugas dalam membalas reservasi' yang nilainya sebesar 4,47. Rata-rata keseluruhan persepsi pelanggan terhadap kualitas layanan media reservasi hotel adalah sebesar 3,20 atau sama dengan $64 \%$. Nilai tersebut menunjukkan bahwa persepsi pelanggan terhadap kualitas layanan media reservasi dalam kategori cukup yang tentunya masih berada satu tingkat di bawah kategori baik atau dua tingkat di bawah kategori sangat baik. Perhatian khusus harus diberikan kepada aspekaspek yang nilainya hampir mendekati kurang yaitu 'Penggunaan kata oleh petugas reservasi dalam mengirim data' dan 'Kemudahan menghubungi PT. Jaya Prima melalui telepon'. 
Beberapa faktor dari kelima dimensi kualitas layanan tersebut telah berada pada kategori baik, tepatnya pada dimensi assurance yaitu 'Kejelasan informasi yang diberikan melalui media telepon dan 'Respon dan tanggapan petugas reservasi dalam membalas reservasi yang diinginkan tamu'.2). Ekspektasi pelanggan terhadap kualitas layanan media reservasi hotel di PT. Jaya Prima Bandung. Berdasarkan hasil analisis yang telah dilakukan dapat disimpulkan bahwa nilai rata-rata ekspektasi (harapan) pelanggan terhadap kualitas layanan media reservasi hotel menunjukkan bahwa aspekaspek dari kelima dimensi kualitas jasa dianggap sangat penting. Nilai rata-rata tertinggi adalah 3,83 dan hal ini menghasilkan penilaian ratarata keseluruhan terhadap penilaian ekspektasi (harapan) pelanggan sebesar 3,39. Secara umum, kepuasan pelanggan di PT. Jaya Prima Bandung dapat dilihat dari gap atau perbedaan antara persepsi dan ekspektasi pelanggan dalam menggunakan layanan media reservasi hotel. Pada studi ini, perbedaan tersebut menunjukkan nilai sebesar -0,19 yang menunjukkan bahwa tingkat kepuasan pelanggan dalam melakukan reservasi hotel melalui media di PT. Jaya Prima Bandung belum seluruhnya terpenuhi. Hal ini disebabkan masih banyaknya aspek dari dimensi kualitas layanan media reservasi hotel yang belum mencapai tingkat 'sangat baik' yang dapat memberikan kepuasan kepada para pelanggan. 3). Hubungan antara kualitas layanan media reservasi hotel dengan kepuasan pelanggan yang melakukan reservasi hotel melalui media dapat dikategorikan mempunyai hubungan yang kuat. Hal ini didapat dari perhitungan korelasi antara variable kualitas layanan media reservasi dan kepuasan pelanggan dengan menggunakan metode Spearman Rank yang menghasilkan hubungan sebesar 0,789. Hasil tersebut membuktikan dugaan penulis mengenai masalah yang dibahas dalam penelitian ini yang mengungkapkan bahwa belum optimalnya kualitas layanan media reservasi hotel berdampak kepada ketidakpuasan pelanggan dalam melakukan reservasi hotel.

Berdasarkan analisis yang dilakukan pada Bab IV, penulis mengajukan beberapa rekomendasi yang bersifat operasional untuk setiap aspek yang memiliki bobot nilai kurang atau di bawah rata-rata, sebagai berikut : 1). Petugas reservasi hotel di PT. Jaya Prima Bandung seharusnya lebih memperhatikan dan memastikan benar penggunaan kata dan kalimat 
yang digunakan dalam mengirim data reservasi

melalui media fax dan internet agar kejelasan informasi yang akan disampaikan dapat dicerna dengan mudah oleh para pelanggan yang menerima data reservasi tersebut. Sebaiknya diadakan pelatihan khusus untuk para petugas reservasi agar kemampuan dan pengetahuan yang dimiliki menjadi lebih baik, khususnya dalam menggunakan kata dan kalimat yang digunakan oleh petugas reservasi untuk mengirim data reservasi melalui media fax dan internet guna menghindari misunderstanding antara petugas reservasi dengan para pelanggan PT. Jaya Prima Bandung. 2). Pihak PT. Jaya Prima Bandung harus mengutamakan para pelanggan yang melakukan reservasi kamar hotel melalui media baik itu media telepon, fax, internet karena mereka telah memberikan kepercayaan sepenuhnya kepada pihak PT. Jaya Prima dalam memenuhi kebutuhan mereka akan produk kamar hotel. Untuk mencegah kekecewaan para pelanggan baik yang melakukan reservasi melalui media ataupun walking guest, pihak PT. Jaya Prima harus menambah divisi dalam reservasi kamar hotel dengan menugaskan sebagian karyawannya khusus untuk menerima reservasi para pelanggan yang melakukan reservasi melalui media, baik itu media telepon, fax atau internet. Hal ini dilakukan agar para petugas reservasi dapat lebih fokus pada tugas dan tanggungjawab masing-masing dan yang lebih pentingnya lagi para pelanggan tidak merasa kecewa akibat dari ketidakmudahan dan ketidaknyamanan dalam melakukan reservasi hotel melalui media. Pihak manajemen diharapkan mampu untuk mengadaptasi model dari kualitas layanan media reservasi hotel untuk lebih meningkatkan tingkat produktivitasnya. Untuk keberhasilan kegiatan reservasi pada sebuah perusahaan, maka diperlukan masukan. Masukan ini misalnya berasal dari data kebutuhan pelanggan yang melakukan reservasi kamar hotel melalui media baik itu media telepon, fax, ataupun internet. Setelah diadakan analisis dari proses reservasi melalui beberapa media tersebut, akhirnya munculah output (keluaran), yaitu berupa suatu informasi baru yang dibutuhkan para pelanggan. Setelah informasi itu diperoleh pelanggan dan dijadikan suatu pencapaian kebutuhan oleh meraka, ditunggu bagaimana hasil tanggapan pelanggan yang telah melaksanakan reservasi kamar hotel melalui media. Inilah yang disebut feedback (balikan) yang sangat 
berguna bagi pihak industry jasa untuk memperbaiki system penanganan reservasi.

\section{REFERENSI}

Ajayi. A'isha , 1999. Pocket guide to telecommunications. electronic communications. And information technology, Canada: Demar Publishers,

Baker, S. Bradley, P. \& Huyton. J. 2000. Principles of hotel front office operations (2nd ed), London: Continuum,

Cooper, Chris, dkk., 1996. Tourism Principle and Practic., England, Long Group Limitied

Clarke. A, 2005, 27 May. Does the GDS code really matter?, TRAVEL WEEKLY vol. 146,6 ,

Cox, B. \& Koelzer. W, 2004. Internet marketing hospitality. New Jersey: Prentice Hall.,

Engst, A.C., Low, C.S., \& Simon, M.A, 1995. Internet Starter kit for window (2nd), Indianapolis: Hayden Books,

Facsimile $W W W$ user survey. (n.d). August 16, 2005. http://education.yahoo.com/reference/dictionary

Grant, A.E, 1996. Communication technology update (5th ed), Boston: Butterworth Heinemann,

Garner, P.A., 1993. Using the office telephone effectively, New Jersey: Prentice Hall,

Hogan, D., 2004. Starwood hires marketing director for its southwest online bookings., Journal of knight ridder tribune business News, 1

Hsu, Cathy H. C. and Powers, Tom (2009) Marketing Hospitality. Canada: John Wiley \& Sons, Inc.

Irawan, Handi. 2002. 10 Prinsip Kepuasan Pelanggan. Jakarta : PT. Elex Media Komputindo

Janal D.S, 1995. Online marketing handbook : how to sell, advertise, publicize, and promote your product and service on the internet and commercial online system.,
New York: Van Nostrand Reinhold,

Kotler, Philip. 1994. Marketing Management : Analysis, Planning, Implemantation, and Control 8th edition.,USA, Prentice Hall International Edition.

Kotler, Philip \& Gary Amstrong. 1997. Principle of Marketing, Seventh Edition. New. Jersey, Prentice Hall Inc.

Lupiyadi, Rambat. 2001. Manajemen Pemasaran Jasa Teori Dan Praktik. Jakarta : PT. Salemba Emban Patria

La Quey, T., 1997. Internet companion, a beginner's guide to global networking. (Hans J. Wospakrik), Bandung: ITB.

Longman 2001. Dictionary of Contemporer English, England : Pearson Education Limited.

Oxford University Press, 1995. Oxford learner'e dictionary (5th ed), London : Walton Street.

Strauss, J., El-Ansary, A,. \& Frost, R. E-marketing (3th ed). Upper Saddle River, New Jersey : Pearson Education, Inc.

Hogan, D. 2004. Starwood hires marketing director for its southwest online bookings., Journal of knight ridder tribune business News, 1.

Sugiyono, Prof. Dr., 2004. Metode penelitian administrasi (cetakan kesebelas, Bandung: Alfabeta.

Soetjipto, Budi W. 2001. Manajemen Produk dan Jasa. Yogyakarta : Andi

Sugiyono, Prof. Dr., 2005. Memahami penelitian kualitatif, Bandung: Alfabeta.

Tjiptono, F. 1995. Strategi Pemasaran. Yogyakarta : Penerbit Andi Offset

Tjiptono, F dan Chandra, G. 2005. Service quality \& Satisfaction Yogyakarta : Penerbit Andi Offset.

Tjiptono, F dan Diana, A. 2001. Total quality Management. Yogyakarta : Penerbit Andi Offset.

Telephone $W W W$ user survey. (n.d). August 16, 2005. http://education.yahoo.com/ 
reference/dictionary

Wearne, N. \& Baker, K., 2002. Hospitality marketing in the e-commerce age (2nd)., New South Wales : Frenchs Forest, Zeithaml, Valeria, A dan Marie, Jo Bitner. 1996. Service Marketing. New York : Mc Graw Hill, Inc. 